\section{JAW-DROPPING NEW TREATMENT FOR TMJ DISORDERS}

A revolutionary new way to treat temporomandibular joint (TMJ) disorders has been approved for use in the UK and Ireland. The Cerezen ${ }^{\mathrm{TM}}$ device comprises a pair of removable custom-made hollow inserts which are placed within the ear canal to reduce the symptoms of TMJ disorders, pain and related conditions including grinding of teeth and headaches.

Simply inserted in the ear, the nearest access point to the TMJ, the device works by exerting subtle pressure on the walls of the ear canal when the jaw is in the closed position. This encourages the patient to return to the 'open bite' position, minimising the tendency to clench the jaw and tense the surrounding muscles. An A Level 1 Clinical Study ${ }^{1}$ showed that $100 \%$ of users indicated excellent (71\%) or good (29\%) overall satisfaction with the Cerezen $^{\mathrm{TM}}$ device.

Following regulatory approval, the Cerezen ${ }^{\mathrm{TM}}$ device will be available in the UK from May 2015 and can be seen at The Dentistry Show, the Irish Dental Association Show and Identex, where there will also be presentations for the delegates to learn more about this innovative new device.

For more information about the device, visit www.cerezen.eu.

1. A Level 1 Clinical Study, reference number NCT00815776.

\section{HAVE YOU CONNECTED YET?}

The Sirona Connect software and CEREC Connect portal from Sirona Dental Systems simplify the communication between your practice and the dental laboratory. Following registration both surgery and lab will be able to communicate via a shared software platform, transmitting data models in just a few seconds. This allows you to discuss important issues with the technician before the patient even leaves the practice.

With this unprecedented degree of accuracy, enhanced detail reproduction at the margins, automatic capture and shake-free images, Sirona Connect produces precise optical digital 3D impressions every time.

Sirona Connect caters for single tooth restorations such as inlays, onlays, veneers, anatomically sized crowns and bridgework. The upgradeability of CEREC and its developments can be easily integrated into existing CEREC systems offering you flexibility.

For further information on Sirona Connect call 08450715040 or email mark.buckland@sironadental. co.uk.
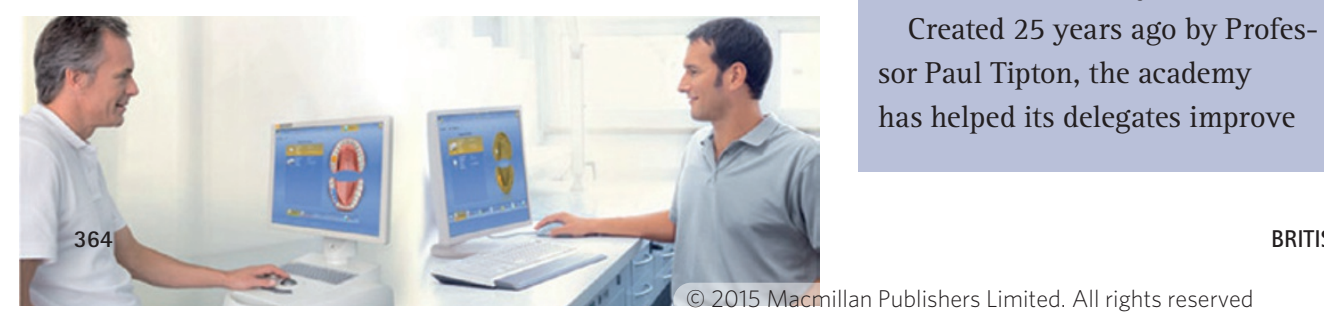

Tipton Training has conducted a survey which shows that private dentists who invest in training per month on average as a direct result. That's $£ 30,000$ per annum or an awful lot of NHS overtime.

Tipton Training, which has teaching locations in Manchester and London, offer a wide variety of courses for private dentists.

Delegates can study the fields of restorative, implant and cosmetic dentistry through a mixture of practical training seminars and theoretical lectures under the direct supervision of qualified specialists and dentists.

Courses come in a variety of formats, including postgraduate, corporate, one-to-one, one day and international syllabuses.

Created 25 years ago by Profeshas helped its delegates improve are likely to earn $£ 2,500$ more

\section{AN INNOVATIVE SOLUTION TO HELP WITH PLAQUE MANAGEMENT}

Plaque is a major cause of gum disease $^{1}$ and according to the Group B consensus report of the fifth European Workshop in Periodontology, '...oral plaque biofilm disruption is the most effective way to treat and prevent both conditions [gingivitis and periodontitis]'.2

In line with this, LISTERINE ${ }^{\circledR}$ Advanced Defence Gum Treatment is clinically proven to interrupt the plaque colonisation process. ${ }^{3}$

LISTERINE $^{\circledR}$ Advanced Defence Gum Treatment is formulated with unique LAE (ethyl lauroyl arginate) technology that forms a physical coating on the pellicle to prevent bacteria attaching, and so interrupts biofilm formation. When used after brushing it treats gum disease, as indicated by the reduction of bleeding by $50.9 \%$ ( $p<0.001$ ) in only four weeks. ${ }^{3}$

Advanced Defence Gum Treatment is part of the LISTERINE $^{\circledR}$ Advanced Defence range from
Johnson \& Johnson, a scientifically proven adjunct to your professional treatment.

For more information on LISTERINE ${ }^{\circledR}$ Advanced Defence, visit www. listerineprofessional. co.uk or call 08003280750.

1. Page R C, Kornman K S. The pathogenesis of human periodontitis: an introduction. Periodontol 2000 1997; 14: 9-11.

2. Kinane $D F$, Attstrom R. Advances in the pathogenesis of periodontitis. Group B consensus report of the fifth European Workshop in Periodontology. J Clin Periodonto/ 2005; 32(Suppl 6): 130-131.

3. Bleeding Index Reduction DOF 1 - 2013 (LAEBBA0001), 50.9\% Reduction in wholemouth mean Bleeding Index at 4 weeks

\title{
INVEST IN TRAINING AND INCREASE YOUR INCOME
}

their careers by enrolling on its dentistry courses. By taking these courses, many private dentists have seen a large rise in their income.

Tipton Training courses also help build confidence and enjoyment in what can be considered a challenging career. Lecturers teach the best practices across a range of disciplines in a way that makes them understandable and easy to implement, through a mixture of practical and theoretical modules.

Successful completion of Tipton Training's dentistry courses can also lead to delegates being accepted into the third year of either the MClinDent Restorative and Cosmetic degree, or the MClinDent Dental Implantology degree.

For further information, visit www.tiptontraining.co.uk or call 01613487848. 